\title{
Pengaruh Konsentrasi Besi dan Tekanan Aerasi terhadap Pertumbuhan Tajuk dan Hasil Sawi Hijau (Brassica Juncea (L.) Czern) pada Sistem Hidroponik Rakit Apung
}

\section{The Effect of Iron Concentration and Aeration Pressure Toward the Shoot Growth and Product of Mustrad Green (Brassica Juncea (L.) Czern) in Raft Hydroponic System}

\author{
Okti Wulandari ${ }^{1}$, Didik Indradewa ${ }^{2^{*}}$, Eka Tarwaca Susila Putra ${ }^{2)}$ \\ 1) Program Studi Agronomi, Fakultas Pertanian, Universitas Gadjah Mada \\ ${ }^{2)}$ Departemen Budidaya Pertanian, Fakultas Pertanian, Universitas Gadjah Mada \\ ${ }^{*}$ Penulis untuk korespodensi E-mail: didikindradewa54@yahoo.com
}

\begin{abstract}
The aims of this research were to learn about the effect of iron concentration and aeration pressure toward the shoot growth, product, and Fe content of mustard green also determine the optimum of iron concentration and aeration pressure to maximize shoot growth and product of mustard green. The research was conducted in greenhouse of Soil Science Department, Agriculture Faculty, Gadjah Mada University, Yogyakarta from April until May 2014. The research was arranged in split plot design. Factor of aeration pressure as main plot consisted of $0 \mathrm{mPa} ; 0,003 \mathrm{mPa} ; 0,006 \mathrm{mPa}$; $0,012 \mathrm{mPa}$. Factor of iron concentration as sub plot consisted of $0 \mathrm{ppm}, 3 \mathrm{ppm}, 6 \mathrm{ppm}$, and $9 \mathrm{ppm}$. The results of the research showed there was no interaction between iron concentration and aeration pressure in almost observation variables. Aeration pressure treatment in the amount of $0.003 \mathrm{mPa}$; 0,006 $\mathrm{mPa}$ and $0,012 \mathrm{mPa}$ really did not influence toward shoot growth, product, and Fe content of mustard green. This is influenced by the depth of relatively shallow hydroponic nutrient solution, so the concentration of dissolve oxygen measured is quite high at all levels of aeration pressure treatment. Iron concentration treatment $0 \mathrm{ppm}$ could inhibit shoot growth and caused death of the mustard green. Treatment of iron concentration at $3 \mathrm{ppm}$ has growth effects as good as iron concentration $6 \mathrm{ppm}$ and $9 \mathrm{ppm}$. Increase of iron concentration until 9 ppm could increased iron content in mustard green tissue and iron absorption.
\end{abstract}

Keywords: mustard green, iron concentration, aeration pressure, hydroponic, floating raft

\section{INTISARI}

Penelitian ini bertujuan untuk mempelajari pengaruh konsentrasi besi dan tekanan aerasi larutan nutrisi hidroponik terhadap pertumbuhan tajuk, hasil, dan kadar Fe sawi hijau serta menentukan konsentrasi besi dan tekanan aerasi larutan nutrisi hidroponik 
rakit apung yang optimal untuk memaksimalkan pertumbuhan tajuk, hasil, kadar Fe sawi hijau. Penelitian dilaksanakan di rumah kaca Departemen IImu Tanah, Fakultas Pertanian, Universitas Gadjah Mada, Yogyakarta pada bulan April sampai Mei 2014. Penelitian ini menggunakan rancangan percobaan petak belah. Faktor tekanan aerasi sebagai petak utama yaitu $0 \mathrm{mP} ; 0,03 \mathrm{mPa}$; 0,006 $\mathrm{mPa}$; dan 0,012 $\mathrm{mPa}$. Faktor konsentrasi Fe sebagai anak petak meliputi 0 ppm, 3 ppm, 6 ppm, dan 9 ppm. Hasil penelitian menunjukkan bahwa tidak terdapat interaksi antara konsentrasi besi dan tekanan aerasi terhadap hampir semua variabel pengamatan. Perlakuan tekanan aerasi tidak berpengaruh nyata terhadap pertumbuhan tajuk, hasil, dan kadar Fe sawi hijau. Hal ini dipengaruhi oleh kedalaman larutan nutrisi hidroponik yang relatif dangkal, sehingga konsentrasi oksigen terlarut yang terukur cukup tinggi di semua level perlakuan tekanan aerasi. Perlakuan konsentrasi $\mathrm{Fe} 0$ ppm menyebabkan pertumbuhan tajuk sawi terhambat, sehingga menyebabkan kematian sawi hijau. Perlakuan konsentrasi Fe 3 ppm memiliki pertumbuhan tajuk dan hasil yang sama baiknya dengan perlakuan konsentrasi 6 ppm dan 9 ppm. Peningkatan konsentrasi Fe sampai 9 ppm dapat meningkatkan kadar Fe dalam jaringan sawi hijau dan serapan $\mathrm{Fe}$.

Kata kunci : sawi hijau, konsentrasi besi, tekanan aerasi, hidroponik, rakit apung

\section{PENDAHULUAN}

Zat besi merupakan nutrisi penting yang dibutuhkan oleh manusia. Defisiensi zat besi dapat menyebabkan anemia. Di Indonesia, defisiensi zat besi merupakan masalah yang paling sulit ditanggulangi. Salah satu kelompok yang kasus anemia karena defisiensi besi adalah kelompok anak sekolah. Angka prevalensi anemia pada kelompok ini cukup tinggi (Notoatmodjo, 2003).

Salah satu cara untuk mengatasi defisiensi besi yang mudah dijangkau secara ekonomi oleh segenap lapisan masyarakat adalah melalui program biofortifikasi Fe pada bahan pangan berbasis sayuran segar (Arisman, 2004). Pada penelitian ini komoditas sayuran segar yang dikaji adalah sawi hijau karena memilikinilai gizi cukup tinggi dan digemari oleh sebagian masyarakat. Menurut Direktorat Gizi Republik Indonesia (1981) kandungan dan komposisi gizi sawi hijau tiap 100 gram bahan yaitu : 21,0 kal energi; $1,8 \mathrm{~g}$ protein; 0,3 g lemak; 3,9 g karbohidrat; 0,7 g serat; 0,9 g abu; $33,0 \mathrm{mg}$ fosfor; 4,4 mg zat besi; 20,0 mg natrium; 323,0 mg kalium; 3.600,0 SI vitamin A; 0,1 mg thiamin; 0,1 $\mathrm{mg}$ riboflavin; $1,0 \mathrm{mg}$ niacin; $74,0 \mathrm{mg}$ vitamin C, dan $147,0 \mathrm{mg}$ kalsium.

Biofortifikasi Fe pada sawi hijau dapat dengan mudah dilakukan apabila dibudidayakan dengan sistem hidroponik rakit apung. Konsentrasi Fe dalam sayuran sawi hijau dapat dengan mudah ditingkatkan melalui penambahan proporsi Fe dalam nutrisi hidroponik yang diaplikasikan. Penambahan konsentrasi Fe dalam larutan nutrisi 
Okti Wulandari et al., / Vegetalika. 2017. 6(4): 41-54

hidroponik menyebabkan tanaman sawi hijau mampu menyerap Fe lebih banyak, sehingga secara otomatis konsentrasinya dalam jaringan daun meningkat menjadi lebih tinggi jika dibandingkan dengan sawi hijau yang tidak mendapatkan perlakuan biofortifikasi.

Peningkatan serapan Fe sawi hijau selain ditentukan oleh proporsinya dalam larutan nutrisi hidroponik juga ditentukan oleh kapasitas sistem perakarannya. Kapasitas sistem perakaran sawi hijau dalam menyerap $\mathrm{Fe}$ ditentukan oleh karakteristik akar dan konsentrasi oksigen terlarut dalam media hidroponik. Pada hidroponik rakit apung, peningkatan konsentrasi oksigen terlarut dalam larutan nutrisi secara mekanis dapat dilakukan dengan memasang aerator (Mizar et al., 1997 cit. Febriani, 2011).

Mendasarkan penjelasan tersebut, peningkatan kadar Fe sawi hijau diduga dapat dilakukan dengan meningkatkan konsentrasi Fe dalam larutan nutrisi hidroponik dan memperkuat laju serapan $\mathrm{Fe}$ oleh sistem perakaran melalui peningkatan konsentrasi oksigen terlarut dalam larutan nutrisi hidroponik secara mekanik menggunakan aerator. Oleh karena itu, penelitian yang mengkaji pengaruh konsentrasi Fe dan tekanan aerasi dalam larutan nutrisi hidroponik rakit apung terhadap pertumbuhan tajuk, kuantitas dan kualitas hasil sawi hijau cukup penting untuk dilaksanakan. Penelitian ini bertujuan mempelajari pengaruh konsentrasi $\mathrm{Fe}$ dan tekanan aerasi dalam larutan nutrisi hidroponik rakit apung terhadap pertumbuhan tajuk, hasil, dan kadar Fe sawi hijau (Brassica juncea L. Czern) dan menentukan konsentrasi Fe dan tekanan aerasi larutan nutrisi hidroponik rakit apung yang optimal untuk memaksimalkan pertumbuhan tajuk, hasil, dan kadar Fe sawi hijau (Brassica juncea L. Czern).

\section{BAHAN DAN METODE}

Penelitian dilaksanakan pada bulan April sampai dengan Mei 2014 di rumah kaca Departemen IImu Tanah, Sub-Laboratorium Ekologi Tanaman, Sub-Laboratorium IImu Tanaman, dan Sub-Laboratorium Manajemen Produksi Tanaman, Fakultas Pertanian, Universitas Gadjah Mada, Yogyakarta. Analisis jaringan untuk mengetahui kadar Fe dilaksanakan di Laboratorium Che-mix Pratama, Banguntapan, Bantul.

Bahan yang digunakan dalam penelitian ini adalah benih sawi hijau varietas Tosakan produksi PT Known-You Seed Indonesia, nutrisi hidroponik (dengan sumber Fe berasal dari Fe-EDTA), styrofoam, busa, dan air. Sedangkan alat yang digunakan dalam penelitian meliputi 96 bak media dengan ukuran $35 \mathrm{~cm} \times 30 \mathrm{~cm} \times 15 \mathrm{~cm}$, aerator 
tipe Sweet AR-8 dengan tekanan aerasi 0,012 mPa, selang ukur diameter $1 / 4$ inch, air stone, kran pengatur tekanan, staker listrik, penggaris, alat tulis, selotip, gelas ukur, beaker glass, tabung reaksi, timbangan analitik, oven, jangka sorong, lux meter, Spectronic 21 D, EC meter, pH meter, termohigrometer dan DO Kit.

Penelitian disusun dalam percobaan petak belah (Split Plot Design). Faktor tekanan aerasi sebagai petak utama dan konsentrasi Fe dalam larutan sebagai anak petak. Faktor tekanan aerasi dalam media tanam yang diuji dalam penelitian meliputi a) $0 \mathrm{mPa}(\mathrm{A} 0$ ), b) $0,003 \mathrm{mPa}(\mathrm{A} 4)$, c) $0,006 \mathrm{mPa}$ (A2), d) 0,012 $\mathrm{mPa}$ (A1). Faktor konsentrasi Fe yang diuji pada penelitian ini terdiri atas empat aras yaitu 0 ppm (Fe1), 3 ppm (Fe3), 6 ppm (Fe6), dan 9 ppm (Fe9). Tata laksana pada penelitian ini meliputi persiapan media pesemaian, pesemaian, perakitan maket hidroponik rakit apung, pemberian larutan nutrisi, pindah tanam, pemeliharaan, dan panen. Secara keseluruhan terdapat 16 kombinasi perlakuan. Setiap perlakuan pada masing-masing ulangan terdapat 18 tanaman sawi hijau, yang meliputi 9 tanaman yang diamati secara periodik sekaligus digunakan sebagai sampel dalam panen akhir (35 hspt) dan 9 tanaman dipanen pada umur 21 hspt. Keseluruhan terdapat 864 tanaman sawi hijau. Variabel yang diamati meliputi: kadar Fe, serapan Fe, kadar klorofil total, jumlah daun, luas daun, laju asimilasi bersih (LAB), laju pertumbuhan nisbi (LPN), tinggi tanaman, diameter batang, bobot segat tajuk, bobot segar total, bobot kering tajuk, bobot kering total, indeks panen (IP), indeks konsumsi (IK), dan konsentrasi oksigen terlarut. Data hasil pengamatan yang telah diperoleh selanjutnya dianalisis varian (ANOVA) pada taraf $5 \%$. Apabila hasil ANOVA menunjukkan perbedaan nyata antara perlakuan, pengujian dilanjutkan dengan Duncan's Multiple Range Test (DMRT) taraf 5\%.

\section{HASIL DAN PEMBAHASAN}

Menurut hasil penelitian ini, hampir semua variabel pengamatan tidak terdapat interaksi antara perlakuan konsentrasi Fe dengan tekanan aerasi terhadap pertumbuhan tajuk dan hasil sawi hijau. Unsur Fe merupakan unsur esensial yang dibutuhkan tanaman. Unsur Fe berperan sebagai komponen penyusun ferredoksin, protein Fe-S, sitokhrom, sitokhrom oksidase yang berperan penting dalam reaksi fotosintesis (Lakitan, 2008). 
Okti Wulandari et al., / Vegetalika. 2017. 6(4): 41-54

Tabel 1. Kadar Fe jaringan sawi hijau (ppm) umur 35 hspt

\begin{tabular}{|c|c|c|c|c|c|}
\hline \multirow[b]{2}{*}{$\begin{array}{c}\text { Konsentrasi } \\
\mathrm{Fe}\end{array}$} & \multicolumn{4}{|c|}{ Tekanan Aerasi } & \multirow[b]{2}{*}{ Rerata } \\
\hline & $\begin{array}{l}0 \\
\mathrm{mPa}\end{array}$ & $\begin{array}{r}0,003 \\
\mathrm{mPa}\end{array}$ & $\begin{array}{c}0,006 \\
\mathrm{mPa}\end{array}$ & $\begin{array}{c}0,012 \\
\mathrm{mPa}\end{array}$ & \\
\hline $0 \mathrm{ppm}$ & 0,000 & 0,000 & 0,000 & 0,000 & 0,000 \\
\hline $3 \mathrm{ppm}$ & 0,223 & 0,433 & 0,332 & 0,453 & 0,360 \\
\hline $6 \mathrm{ppm}$ & 0,215 & 0,333 & 0,281 & 0,266 & 0,274 \\
\hline $9 \mathrm{ppm}$ & 0,254 & 0,296 & 0,871 & 0,283 & 0,426 \\
\hline Rerata & 0,231 & 0,354 & 0,495 & 0,334 & \\
\hline
\end{tabular}

Berdasarkan hasil penelitian, kadar Fe dalam jaringan tanaman sawi hijau meningkat sejalan dengan kenaikan konsentrasi Fe dalam larutan nutrisi hidroponik sampai dengan $9 \mathrm{ppm}$. Kecenderungan yang masih linier pada hubungan antara perlakuan konsentrasi $\mathrm{Fe}$ dalam larutan nutrisi dengan kadar $\mathrm{Fe}$ jaringan sampai dengan konsentrasi Fe 9 ppm mengindikasikan adanya potensi untuk menaikkan kadar Fe dalam jaringan melalui peningkatan konsentrasi Fe yang diberikan pada tingkatan lebih tinggi dari 9 ppm (Gambar 1).

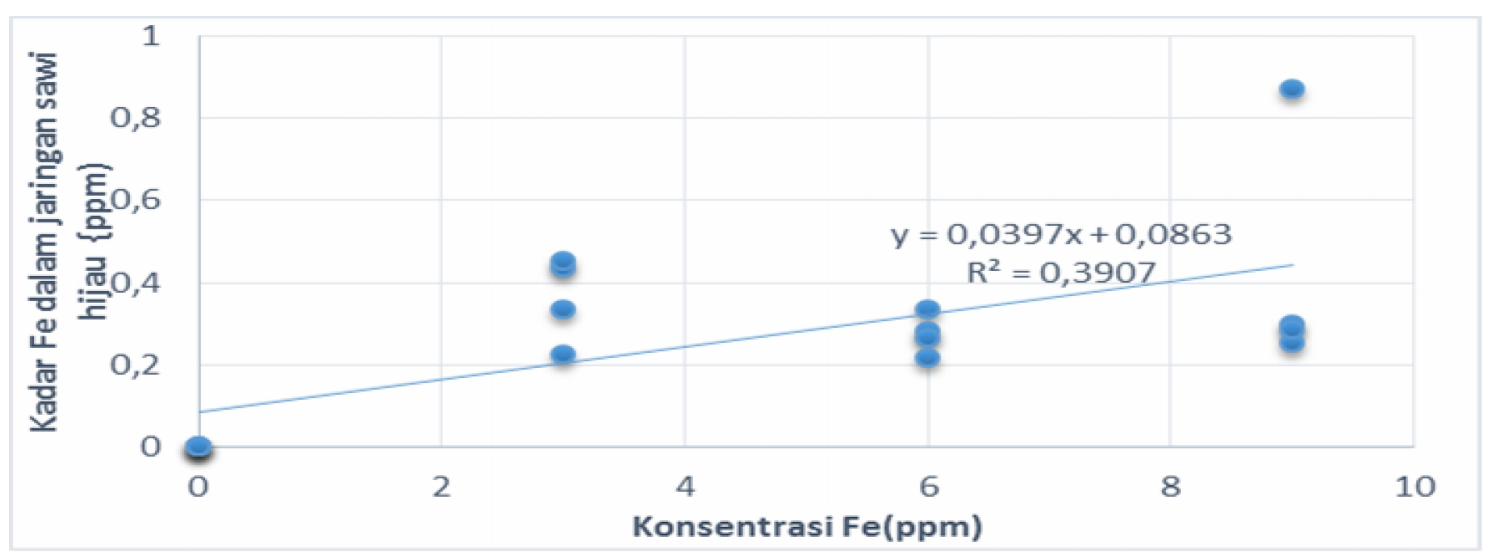

Gambar 1. Hubungan regresi konsentrasi Fe dalam larutan nutrisi hidroponik terhadap kadar Fe dalam jaringan sawi hijau

Tabel 2. Serapan Fe oleh tanaman sawi hijau umur 35 hst

\begin{tabular}{cccccc}
\hline \multirow{2}{*}{ Konsentrasi Fe } & \multicolumn{4}{c}{ Tekanan Aerasi } & \multirow{2}{*}{ Rerata } \\
\cline { 2 - 5 } & $0 \mathrm{mPa}$ & $0,003 \mathrm{mPa}$ & $0,006 \mathrm{mPa}$ & $0,012 \mathrm{mPa}$ & \\
\hline $0 \mathrm{ppm}$ & $0,000 \mathrm{~d}$ & $0,000 \mathrm{~d}$ & $0,000 \mathrm{~d}$ & $0,000 \mathrm{~d}$ & 0,000 \\
$3 \mathrm{ppm}$ & $0,614 \mathrm{c}$ & $1,351 \mathrm{~b}$ & $0,792 \mathrm{c}$ & $1,438 \mathrm{~b}$ & 1,049 \\
$6 \mathrm{ppm}$ & $0,705 \mathrm{c}$ & $0,922 \mathrm{c}$ & $0,840 \mathrm{c}$ & $0,796 \mathrm{c}$ & 0,816 \\
$9 \mathrm{ppm}$ & $0,777 \mathrm{c}$ & $0,906 \mathrm{c}$ & $2,034 \mathrm{a}$ & $0,730 \mathrm{c}$ & 1,112 \\
\hline Rerata & 0,524 & 0,795 & 0,917 & 0,714 & $(+)$ \\
\hline CV & \multicolumn{5}{c}{$18,797 \%$} \\
\hline
\end{tabular}

Keterangan: Angka-angka pada kolom atau baris yang sama diikuti huruf yang sama, tidak berbeda nyata pada uji Duncan dengan tingkat signifikansi $5 \%$. Tanda $(+)$ menunjukkan ada interaksi 
Kadar Fe dalam jaringan tanaman sawi hijau dipengaruhi oleh serapan Fe oleh tanaman. Semakin tinggi serapan Fe, maka semakin tinggi kadar Fe dalam jaringan tanaman. Serapan Fe tertinggi terdapat pada perlakuan konsentrasi Fe 9 ppm dan tekanan aerasi 0,006 $\mathrm{mPa}$ (Tabel 2). Besi yang diserap tanaman sawi hijau digunakan sebagai pembentuk ultrastruktur kloroplas, sehingga berpengaruh terhadap tingkat klorofil pada organ daun. Tanaman sawi hijau yang tidak diberi Fe pada larutan nutrisi memiliki kadar klorofil total terendah. Tanaman mengalami hambatan dalam membentuk kloroplas karena mengalami defisiensi Fe (Tabel 3 dan Tabel 4).

Tabel 3. Kadar klorofil total umur $21 \mathrm{hspt}$ ( $\mathrm{mg} / \mathrm{g}$ bobot daun)

\begin{tabular}{cccccc}
\hline \multirow{2}{*}{ Konsentrasi Fe } & \multicolumn{4}{c}{ Tekanan Aerasi } & \multirow{2}{*}{ Rerata } \\
\cline { 2 - 5 } & $0 \mathrm{mPa}$ & $0,003 \mathrm{mPa}$ & $0,006 \mathrm{mPa}$ & $0,012 \mathrm{mPa}$ & \\
\hline $0 \mathrm{ppm}$ & 0,105 & 0,086 & 0,097 & 0,141 & 0,107 \\
$3 \mathrm{ppm}$ & 0,398 & 0,622 & 0,643 & 0,666 & 0,582 \\
$6 \mathrm{ppm}$ & 0,195 & 0,461 & 0,599 & 0,753 & 0,502 \\
$9 \mathrm{ppm}$ & 0,274 & 0,536 & 0,325 & 0,784 & 0,407 \\
\hline Rerata & 0,243 & 0,426 & 0,416 & 0,576 & \\
\hline
\end{tabular}

Tabel 4. Kadar klorofil total umur $35 \mathrm{hspt}$ ( $\mathrm{mg} / \mathrm{g}$ bobot daun)

\begin{tabular}{cccccc}
\hline \multirow{2}{*}{ Konsentrasi Fe } & \multicolumn{4}{c}{ Tekanan Aerasi } & \multirow{2}{*}{ Rerata } \\
\cline { 2 - 4 } & $0 \mathrm{mPa}$ & $0,003 \mathrm{mPa}$ & $0,006 \mathrm{mPa}$ & $0,012 \mathrm{mPa}$ & \\
\hline $0 \mathrm{ppm}$ & 0,000 & 0,000 & 0,000 & 0,000 & 0,000 \\
$3 \mathrm{ppm}$ & 0,784 & 0,676 & 0,643 & 0,706 & 0,702 \\
$6 \mathrm{ppm}$ & 0,382 & 0,489 & 0,606 & 0,992 & 0,617 \\
$9 \mathrm{ppm}$ & 0,510 & 0,788 & 0,507 & 0,908 & 0,678 \\
\hline Rerata & 0,559 & 0,651 & 0,585 & 0,869 & \\
\hline
\end{tabular}

Tabel 5. Jumlah daun sawi hijau umur $21 \mathrm{hspt}$ dan $35 \mathrm{hspt}$

\begin{tabular}{|c|c|c|c|c|c|}
\hline \multirow{2}{*}{$\begin{array}{c}\text { Konsentrasi } \\
\mathrm{Fe}\end{array}$} & \multicolumn{4}{|c|}{ Tekanan Aerasi } & \multirow{2}{*}{ Rerata } \\
\hline & $0 \mathrm{mPa}$ & $0,003 \mathrm{mPa}$ & $0,006 \mathrm{mPa}$ & $0,012 \mathrm{mPa}$ & \\
\hline \multicolumn{6}{|l|}{$21 \mathrm{hspt}$} \\
\hline $0 \mathrm{ppm}$ & 1,389 & 2,556 & 2,056 & 2,722 & $2,181 \mathrm{q}$ \\
\hline 3 ppm & 5,889 & 6,000 & 5,722 & 6,000 & $5,903 p$ \\
\hline $6 \mathrm{ppm}$ & 5,889 & 5,739 & 6,055 & 5,722 & $5,851 p$ \\
\hline 9 ppm & 6,000 & 5,850 & 6,056 & 6,056 & $5,990 p$ \\
\hline Rerata & $4,792 \mathrm{a}$ & 5,036 a & $4,972 \mathrm{a}$ & $5,125 a$ & $(-)$ \\
\hline $\mathrm{CV}$ & & & $11,280 \%$ & & \\
\hline \multicolumn{6}{|l|}{$35 \mathrm{hspt}$} \\
\hline 0 ppm & 0,000 & 0,000 & 0,000 & 0,000 & $0,000 \mathrm{q}$ \\
\hline 3 ppm & 9,500 & 9,555 & 8,611 & 9,667 & $9,333 p$ \\
\hline 6 ppm & 9,000 & 8,667 & 9,167 & 9,778 & $9,153 p$ \\
\hline 9 ppm & 9,706 & 9,278 & 9,167 & 9,111 & $9,315 p$ \\
\hline Rerata & $7,051 \mathrm{a}$ & $6,875 a$ & $6,736 a$ & $7,139 a$ & $(-)$ \\
\hline $\mathrm{CV}$ & & & $9,050 \%$ & & \\
\hline
\end{tabular}

Kadar klorofil total yang rendah pada sawi hijau perlakuan konsentrasi 0 ppm mengakibatkan pertumbuhan daun menjadi terhambat. Perlakuan konsentrasi Fe 0 
Okti Wulandari et al., / Vegetalika. 2017. 6(4): 41-54

ppm menurunkan jumlah dan luas daun sawi hijau. Pertumbuhan daun pada perlakuan konsentrasi 0 ppm paling rendah disebabkan tanaman mengalami defisiensi besi. Defisiensi besi akan berdampak besar pada berkurangnya protein kloroplas. Pada kondisi kekurangan besi, pembentukan sel terhenti, sehingga pertumbuhan daun menurun (Mohammed dan Aly, 2004). Hal ini ditandai dengan warna daun kuning pucat, tulang daun perlahan mengering, lalu daun rontok.

Tabel 6. Luas daun sawi hijau $\left(\mathrm{cm}^{2}\right)$ pada umur $21 \mathrm{hspt}$ dan $35 \mathrm{hspt}$

\begin{tabular}{|c|c|c|c|c|c|}
\hline \multirow{2}{*}{$\begin{array}{c}\text { Konsentrasi } \\
\text { Fe }\end{array}$} & \multicolumn{4}{|c|}{ Tekanan Aerasi } & \multirow{2}{*}{ Rerata } \\
\hline & $0 \mathrm{mPa}$ & $0,003 \mathrm{mPa}$ & $0,006 \mathrm{mPa}$ & $0,012 \mathrm{mPa}$ & \\
\hline \multicolumn{6}{|l|}{$21 \mathrm{hspt}$} \\
\hline 0 ppm & 6,803 & 17,687 & 7,483 & 14,966 & $11,735 q$ \\
\hline 3 ppm & 285,034 & 324,490 & 338,775 & 322,449 & $317,687 p$ \\
\hline 6 ppm & 310,888 & 276,871 & 319,728 & 320,408 & $306,974 p$ \\
\hline 9 ppm & 263,265 & 300,680 & 318,368 & 293,877 & $294,048 p$ \\
\hline Rerata & $216,498 \mathrm{~b}$ & $229,932 a b$ & $246,089 a$ & $237,925 a b$ & $(-)$ \\
\hline $\mathrm{CV}$ & & & $17,479 \%$ & & \\
\hline \multicolumn{6}{|l|}{35 hspt } \\
\hline $0 \mathrm{ppm}$ & 0,000 & 0,000 & 0,000 & 0,000 & $0,000 \mathrm{q}$ \\
\hline 3 ppm & 714,286 & 700,000 & 659,864 & 856,463 & $732,653 p$ \\
\hline $6 \mathrm{ppm}$ & 832,653 & 750,884 & 770,748 & 850,340 & $801,156 p$ \\
\hline 9 ppm & 730,612 & 885,034 & 709,524 & 630,408 & $738,895 p$ \\
\hline Rerata & 569,388 a & $583,980 \mathrm{a}$ & $535,034 \mathrm{a}$ & $584,303 \mathrm{a}$ & $(-)$ \\
\hline
\end{tabular}

Keterangan: Rerata dalam satu kolom atau baris yang diikuti oleh huruf sama tidak berbeda nyata menurut uji Duncan dengan tingkat kepercayaan 95\%. Tanda ( - ) menunjukkan tidak ada interaksi.

Pertumbuhan daun melambat. Kemudian, tanaman sawi hijau pada perlakuan ini mengalami kematian. Perlakuan konsentrasi Fe 3 ppm, 6 ppm, dan 9 ppm memiliki pertumbuhan jumlah dan luas daun yang seragam (Tabel 5 dan Tabel 6).

Tabel 7. Laju asimilasi bersih $\left(\mathrm{g} / \mathrm{cm}^{2} /\right.$ minggu)

\begin{tabular}{lccccc}
\hline Konsentrasi & \multicolumn{4}{c}{ Tekanan Aerasi } & \multirow{2}{*}{ Rerata } \\
\cline { 2 - 5 } \multicolumn{1}{c}{$\mathrm{Fe}$} & $0 \mathrm{mPa}$ & $0,003 \mathrm{mPa}$ & $0,006 \mathrm{mPa}$ & $0,012 \mathrm{mPa}$ & \\
\hline $0 \mathrm{ppm}$ & $-0,0030$ & $-0,0014$ & $-0,0018$ & $-0,0015$ & $-0,0019 \mathrm{q}$ \\
$3 \mathrm{ppm}$ & 0,0019 & 0,0023 & 0,0014 & 0,0019 & $0,0019 \mathrm{p}$ \\
$6 \mathrm{ppm}$ & 0,0022 & 0,0021 & 0,0019 & 0,0018 & $0,0020 \mathrm{p}$ \\
$9 \mathrm{ppm}$ & 0,0024 & 0,0020 & 0,0015 & 0,0017 & $0,0019 \mathrm{p}$ \\
\hline Rerata & $0,0009 \mathrm{a}$ & $0,0012 \mathrm{a}$ & $0,0008 \mathrm{a}$ & $0,0010 \mathrm{a}$ & $(-)$ \\
\hline CV & & & $75,703 \%$ & & \\
\hline
\end{tabular}

Keterangan: Rerata dalam satu kolom atau baris yang diikuti oleh huruf sama tidak berbeda nyata menurut uji Duncan dengan tingkat kepercayaan 95\%. Tanda ( - ) menunjukkan tidak ada interaksi 
Okti Wulandari et al., / Vegetalika. 2017. 6(4): 41-54

Tabel 8. Laju Pertumbuhan Nisbi (g/g/minggu)

\begin{tabular}{|c|c|c|c|c|c|}
\hline \multirow{2}{*}{$\begin{array}{c}\text { Konsentrasi } \\
\mathrm{Fe}\end{array}$} & \multicolumn{4}{|c|}{ Tekanan Aerasi } & \multirow{2}{*}{ Rerata } \\
\hline & $0 \mathrm{mPa}$ & $0,003 \mathrm{mPa}$ & $0,006 \mathrm{mPa}$ & $0,012 \mathrm{mPa}$ & \\
\hline $0 \mathrm{ppm}$ & $-0,009$ & $-0,008$ & $-0,007$ & $-0,011$ & $-0,009 q$ \\
\hline $3 \mathrm{ppm}$ & 0,874 & 1,100 & 0,686 & 1,054 & $0,928 p$ \\
\hline $6 \mathrm{ppm}$ & 1,151 & 0,958 & 0,957 & 0,991 & $1,014 p$ \\
\hline 9 ppm & 1,114 & 1,085 & 0,699 & 0,772 & $0,917 p$ \\
\hline Rerata & $0,782 \mathrm{a}$ & $0,784 a$ & 0,583 a & $0,702 a$ & $(-)$ \\
\hline $\mathrm{CV}$ & & & $30,178 \%$ & & \\
\hline
\end{tabular}

Tabel 7 dan Tabel 8 memberikan informasi bahwa perlakuan konsentrasi Fe 0 ppm menurunkan laju asimilasi bersih dan laju pertumbuhan nisbi. Sawi hijau yang tidak diberi Fe (0 ppm) memiliki laju asimilasi bersih dan laju pertumbuhan nisbi bernilai negatif. Hal ini dipengaruhi oleh luas permukaan daun yang kecil dan tingkat klorofil daun yang rendah. Laju asimilasi bersih dan laju pertumbuhan nisbi pada konsentrasi Fe 3 ppm, 6 ppm, dan 9 ppm tidak berbeda nyata.

Tabel 9. Bobot segar tajuk sawi hijau (g/tanaman) umur $21 \mathrm{hspt}$ dan $35 \mathrm{hspt}$

\begin{tabular}{|c|c|c|c|c|c|}
\hline \multirow{2}{*}{$\begin{array}{c}\text { Konsentrasi } \\
\mathrm{Fe}\end{array}$} & \multicolumn{4}{|c|}{ Tekanan Aerasi } & \multirow[b]{2}{*}{ Rerata } \\
\hline & $0 \mathrm{mPa}$ & $0,003 \mathrm{mPa}$ & $0,006 \mathrm{mPa}$ & $0,012 \mathrm{mPa}$ & \\
\hline \multicolumn{6}{|l|}{$21 \mathrm{hspt}$} \\
\hline $0 \mathrm{ppm}$ & 0,267 & 0,593 & 0,283 & 0,490 & $0,408 \mathrm{q}$ \\
\hline $3 \mathrm{ppm}$ & 13,850 & 13,343 & 14,710 & 13,753 & $13,914 p$ \\
\hline $6 \mathrm{ppm}$ & 14,373 & 12,340 & 14,390 & 14,480 & $13,896 p$ \\
\hline 9 ppm & 12,757 & 13,337 & 15,117 & 13,953 & $13,791 p$ \\
\hline Rerata & $10,312 a$ & $9,903 \mathrm{a}$ & $11,125 \mathrm{a}$ & 10,669 a & $(-)$ \\
\hline $\mathrm{CV}$ & & & $16,823 \%$ & & \\
\hline \multicolumn{6}{|l|}{$35 \mathrm{hspt}$} \\
\hline $0 \mathrm{ppm}$ & 0,000 & 0,000 & 0,000 & 0,000 & $0,000 \mathrm{q}$ \\
\hline 3 ppm & 41,650 & 47,580 & 38,103 & 46,193 & $43,382 p$ \\
\hline $6 \mathrm{ppm}$ & 46,467 & 42,173 & 42,693 & 46,200 & $44,383 p$ \\
\hline 9 ppm & 42,977 & 47,070 & 42,260 & 38,393 & $42,675 p$ \\
\hline Rerata & $32,774 \mathrm{a}$ & $34,206 \mathrm{a}$ & $30,764 \mathrm{a}$ & 32,697 a & $(-)$ \\
\hline CV & & & $16,758 \%$ & & \\
\hline
\end{tabular}

Keterangan: Rerata dalam satu kolom atau baris yang diikuti oleh huruf sama tidak berbeda nyata menurut uji Duncan dengan tingkat kepercayaan 95\%. Tanda ( - ) menunjukkan tidak ada interaksi. 
Okti Wulandari et al., / Vegetalika. 2017. 6(4): 41-54

Tabel 10. Bobot segar total sawi hijau (g/tanaman) umur 21 dan 35 hspt

\begin{tabular}{|c|c|c|c|c|c|}
\hline \multirow{2}{*}{$\begin{array}{c}\text { Konsentrasi } \\
\text { Fe }\end{array}$} & \multicolumn{4}{|c|}{ Tekanan Aerasi } & \multirow{2}{*}{ Rerata } \\
\hline & $0 \mathrm{mPa}$ & $0,003 \mathrm{mPa}$ & $0,006 \mathrm{mPa}$ & $0,012 \mathrm{mPa}$ & \\
\hline \multicolumn{6}{|l|}{$21 \mathrm{hspt}$} \\
\hline 0 ppm & 0,354 & 0,641 & 0,350 & 0,532 & $0,469 \mathrm{q}$ \\
\hline 3 ppm & 14,689 & 14,071 & 15,580 & 14,684 & $14,756 p$ \\
\hline 6 ppm & 15,296 & 13,047 & 15,282 & 15,329 & $14,739 p$ \\
\hline 9 ppm & 13,531 & 14,456 & 15,950 & 14,863 & $14,700 p$ \\
\hline Rerata & 10,968 a & $10,554 \mathrm{a}$ & $11,791 \mathrm{a}$ & $11,352 \mathrm{a}$ & $(-)$ \\
\hline $\mathrm{CV}$ & & & $16,935 \%$ & & \\
\hline \multicolumn{6}{|l|}{$35 \mathrm{hspt}$} \\
\hline 0 ppm & 0,000 & 0,000 & 0,000 & 0,000 & $0,000 q$ \\
\hline 3 ppm & 44,062 & 49,406 & 40,402 & 48,589 & $45,615 p$ \\
\hline 6 ppm & 49,318 & 44,443 & 45,099 & 48,648 & $46,877 p$ \\
\hline 9 ppm & 45,464 & 49,252 & 44,358 & 40,210 & $44,821 p$ \\
\hline Rerata & $34,711 \mathrm{a}$ & $35,775 a$ & $32,465 \mathrm{a}$ & $34,362 \mathrm{a}$ & $(-)$ \\
\hline $\mathrm{CV}$ & & & $16,538 \%$ & & \\
\hline
\end{tabular}

Keterangan: Rerata dalam satu kolom atau baris yang diikuti oleh huruf sama tidak berbeda nyata menurut uji Duncan dengan tingkat kepercayaan 95\%. Tanda ( - ) menunjukkan tidak ada interaksi.

Tabel 11. Bobot kering tajuk (g/tanaman) pada umur 21 dan 35 hspt

\begin{tabular}{|c|c|c|c|c|c|}
\hline \multirow{2}{*}{$\begin{array}{c}\text { Konsentrasi } \\
\text { Fe }\end{array}$} & \multicolumn{4}{|c|}{ Tekanan Aerasi } & \multirow[b]{2}{*}{ Rerata } \\
\hline & $0 \mathrm{mPa}$ & $0,003 \mathrm{mPa}$ & $0,006 \mathrm{mPa}$ & $0,012 \mathrm{mPa}$ & \\
\hline \multicolumn{6}{|l|}{$21 \mathrm{hspt}$} \\
\hline $0 \mathrm{ppm}$ & 0,017 & 0,013 & 0,013 & 0,019 & $0,015 q$ \\
\hline 3 ppm & 0,958 & 0,874 & 0,961 & 1,007 & $0,950 p$ \\
\hline 6 ppm & 0,926 & 0,800 & 1.017 & 0,950 & $0,923 p$ \\
\hline 9 ppm & 0,783 & 0,840 & 0,879 & 0,988 & $0,873 p$ \\
\hline Rerata & $0,673 a$ & $0,632 \mathrm{a}$ & 0,717 & $0,741 a$ & $(-)$ \\
\hline $\mathrm{CV}$ & & & $25,492 \%$ & & \\
\hline \multicolumn{6}{|l|}{$35 \mathrm{hspt}$} \\
\hline $0 \mathrm{ppm}$ & 0,000 & 0,000 & 0,000 & 0,000 & $0,000 \mathrm{q}$ \\
\hline 3 ppm & 2,634 & 3,004 & 2,272 & 2,982 & $2,723 p$ \\
\hline $6 \mathrm{ppm}$ & 3,109 & 2,659 & 2,836 & 2,836 & $2,860 p$ \\
\hline 9 ppm & 2,891 & 2,910 & 2,201 & 2,387 & $2,597 p$ \\
\hline Rerata & $2,159 a$ & $2,143 a$ & $1,827 \mathrm{a}$ & 2,051 a & $(-)$ \\
\hline $\mathrm{CV}$ & & & $17,706 \%$ & & \\
\hline
\end{tabular}

Keterangan: Rerata dalam satu kolom atau baris yang diikuti oleh huruf sama tidak berbeda nyata menurut uji Duncan dengan tingkat kepercayaan 95\%. Tanda ( - ) menunjukkan tidak ada interaksi. 
Okti Wulandari et al., / Vegetalika. 2017. 6(4): 41-54

Tabel 12. Bobot kering total sawi hijau (g/tanaman) umur 21 dan $35 \mathrm{hspt}$

\begin{tabular}{|c|c|c|c|c|c|}
\hline \multirow{2}{*}{$\begin{array}{c}\text { Konsentrasi } \\
\mathrm{Fe}\end{array}$} & \multicolumn{4}{|c|}{ Tekanan Aerasi } & \multirow{2}{*}{ Rerata } \\
\hline & $0 \mathrm{mPa}$ & $0,003 \mathrm{mPa}$ & $0,006 \mathrm{mPa}$ & $0,012 \mathrm{mPa}$ & \\
\hline \multicolumn{6}{|l|}{$21 \mathrm{hspt}$} \\
\hline $0 \mathrm{ppm}$ & 0,019 & 0,015 & 0,014 & 0,021 & $0,017 \mathrm{c}$ \\
\hline $3 \mathrm{ppm}$ & 1,007 & 0,921 & 1,013 & 1,067 & $1,002 p$ \\
\hline $6 \mathrm{ppm}$ & 0,980 & 0,848 & 1,076 & 1,009 & $0,978 p$ \\
\hline $9 \mathrm{ppm}$ & 0,833 & 0,891 & 0,938 & 1,037 & $0,925 \mathrm{p}$ \\
\hline Rerata & $0,710 \mathrm{a}$ & $0,669 a$ & $0,760 \mathrm{a}$ & $0,784 a$ & $(-)$ \\
\hline $\mathrm{CV}$ & & & $24,792 \%$ & & \\
\hline \multicolumn{6}{|l|}{$35 \mathrm{hspt}$} \\
\hline $0 \mathrm{ppm}$ & 0,000 & 0,000 & 0,000 & 0,000 & $0,000 \mathrm{c}$ \\
\hline $3 \mathrm{ppm}$ & 2,754 & 3,120 & 2,385 & 3,175 & $2,859 p$ \\
\hline $6 \mathrm{ppm}$ & 3,281 & 2,768 & 2,989 & 2,991 & $3,007 p$ \\
\hline $9 \mathrm{ppm}$ & 3,061 & 3,061 & 2,336 & 2,581 & $2,760 p$ \\
\hline Rerata & $2,274 a$ & $2,237 \mathrm{a}$ & $1,928 \mathrm{a}$ & $2,187 a$ & $(-)$ \\
\hline
\end{tabular}

Keterangan: Rerata dalam satu kolom atau baris yang diikuti oleh huruf sama tidak berbeda nyata menurut uji Duncan dengan tingkat kepercayaan 95\%. Tanda (-) menunjukkan tidak ada interaksi

Fotosintat yang dihasilkan berpengaruh pada bobot segar dan bobot kering tanaman. Perlakuan konsentrasi Fe 0 ppm menurunkan bobot segar tajuk, bobot segar total, bobot kering tajuk, dan bobot kering total tanaman sawi hijau umur 21 hspt dan 35 hspt. Konsentrasi Fe 3 ppm, 6 ppm, dan 9 ppm tidak berbeda nyata pada variabel bobot segar tajuk, bobot segar total, bobot kering tajuk, dan bobot kering total tanaman sawi hijau umur 21 hspt dan 35 hspt (Tabel 9, 10,11,12).

Sawi hijau dengan perlakuan konsentrasi Fe $(0 \mathrm{ppm})$ memiliki pertumbuhan tinggi tanaman dan diameter batang yang rendah, sedangkan sawi hijau dengan perlakuan Fe konsentrasi 3 ppm, 6 ppm, dan 9 ppm memiliki tinggi tanaman dan diameter batang yang seragam. Kebutuhan $\mathrm{Fe}$ tanaman sawi hijau pada ketiga perlakuan tersebut tercukupi, sehingga tanaman dapat melakukan aktivitas metabolisme dan pertumbuhan (Tabel 13 dan Tabel 14). 
Okti Wulandari et al., / Vegetalika. 2017. 6(4): 41-54

Tabel 13. Tinggi tanaman sawi hijau (cm) umur 21 hspt dan 35 hspt

\begin{tabular}{|c|c|c|c|c|c|}
\hline \multirow{2}{*}{$\begin{array}{c}\text { Konsentrasi } \\
\mathrm{Fe}\end{array}$} & \multicolumn{4}{|c|}{ Tekanan Aerasi } & \multirow{2}{*}{ Rerata } \\
\hline & $0 \mathrm{mPa}$ & $0,003 \mathrm{mPa}$ & $0,006 \mathrm{mPa}$ & $0,012 \mathrm{mPa}$ & \\
\hline \multicolumn{6}{|l|}{$21 \mathrm{hspt}$} \\
\hline $0 \mathrm{ppm}$ & 2,172 & 2,761 & 2,428 & 3,233 & $2,649 q$ \\
\hline $3 \mathrm{ppm}$ & 3,834 & 4,445 & 3,861 & 4,528 & $4,167 p$ \\
\hline $6 \mathrm{ppm}$ & 3,450 & 4,472 & 3,889 & 4.444 & $4,064 p$ \\
\hline 9 ppm & 3,583 & 4,556 & 4,555 & 4,611 & $4,326 p$ \\
\hline Rerata & $3,260 \mathrm{~b}$ & $4,059 a$ & $3,683 a b$ & $4,204 \mathrm{a}$ & $(-)$ \\
\hline CV & \multicolumn{5}{|c|}{$15,380 \%$} \\
\hline \multicolumn{6}{|l|}{$35 \mathrm{hspt}$} \\
\hline $0 \mathrm{ppm}$ & 0,000 & 0,000 & 0,000 & 0,000 & $0,000 \mathrm{q}$ \\
\hline $3 \mathrm{ppm}$ & 4,833 & 5,444 & 5,261 & 5,834 & $5,343 p$ \\
\hline $6 \mathrm{ppm}$ & 4,445 & 5,844 & 5,278 & 5,231 & $5,200 p$ \\
\hline 9 ppm & 4,167 & 5,594 & 5,917 & 6,161 & $5,460 p$ \\
\hline Rerata & $3,361 \mathrm{~b}$ & $4,221 \mathrm{a}$ & $4,114 a b$ & 4,307 a & $(-)$ \\
\hline $\mathrm{CV}$ & \multicolumn{5}{|c|}{$16,670 \%$} \\
\hline
\end{tabular}

Tabel 14. Diameter batang sawi hijau (mm) pada umur 21 dan $35 \mathrm{hspt}$

\begin{tabular}{|c|c|c|c|c|c|}
\hline \multirow{2}{*}{$\begin{array}{c}\text { Konsentrasi } \\
\mathrm{Fe}\end{array}$} & \multicolumn{4}{|c|}{ Tekanan Aerasi } & \multirow[b]{2}{*}{ Rerata } \\
\hline & $0 \mathrm{mPa}$ & $0,003 \mathrm{mPa}$ & $0,006 \mathrm{mPa}$ & $0,012 \mathrm{mPa}$ & \\
\hline \multicolumn{6}{|l|}{$21 \mathrm{hspt}$} \\
\hline $0 \mathrm{ppm}$ & 0,945 & 1,074 & 0,905 & 0,891 & $0,954 \mathrm{q}$ \\
\hline 3 ppm & 4,861 & 5,248 & 5,250 & 5,731 & $5,273 p$ \\
\hline $6 \mathrm{ppm}$ & 5,528 & 5,158 & 5,284 & 5,312 & $5,321 p$ \\
\hline 9 ppm & 5,284 & 5,106 & 5,451 & 5,142 & $5,246 p$ \\
\hline Rerata & $4,155 a$ & $4,147 \mathrm{a}$ & $4,223 a$ & $4,269 a$ & $(-)$ \\
\hline CV & & & $6,970 \%$ & & \\
\hline \multicolumn{6}{|l|}{$35 \mathrm{hspt}$} \\
\hline $0 \mathrm{ppm}$ & 0,000 & 0,000 & 0,000 & 0,000 & $0,000 \mathrm{q}$ \\
\hline 3 ppm & 9,856 & 10,800 & 10,188 & 11,192 & $10,509 p$ \\
\hline $6 \mathrm{ppm}$ & 10,646 & 9,515 & 11,227 & 10,812 & $10,550 p$ \\
\hline 9 ppm & 9,935 & 11,142 & 11,026 & 10,268 & $10,593 p$ \\
\hline Rerata & $7,609 a$ & $7,864 \mathrm{a}$ & $8,110 \mathrm{a}$ & $8,068 \mathrm{a}$ & $(-)$ \\
\hline $\mathrm{CV}$ & & & $22,270 \%$ & & \\
\hline
\end{tabular}

Keterangan: Rerata dalam satu kolom atau baris yang diikuti oleh huruf sama tidak berbeda nyata menurut uji Duncan dengan tingkat kepercayaan 95\%. Tanda ( - ) menunjukkan tidak ada interaksi. 
Tabel 15. Indeks panen sawi hijau

\begin{tabular}{|c|c|c|c|c|c|}
\hline \multirow{2}{*}{$\begin{array}{c}\text { Konsentrasi } \\
\text { Fe }\end{array}$} & \multicolumn{4}{|c|}{ Tekanan Aerasi } & \multirow{2}{*}{ Rerata } \\
\hline & $0 \mathrm{mPa}$ & $0,003 \mathrm{mPa}$ & $0,006 \mathrm{mPa}$ & $0,012 \mathrm{mPa}$ & \\
\hline \multicolumn{6}{|l|}{$21 \mathrm{hspt}$} \\
\hline 0 ppm & 0,889 & 0,837 & 0,809 & 0,801 & $0,834 \mathrm{q}$ \\
\hline 3 ppm & 0,950 & 0,948 & 0,948 & 0,943 & $0,947 p$ \\
\hline 6 ppm & 0,942 & 0,936 & 0,939 & 0,939 & $0,939 p$ \\
\hline 9 ppm & 0,938 & 0,942 & 0,935 & 0,951 & $0,941 p$ \\
\hline Rerata & $0.930 \mathrm{a}$ & $0,916 a$ & $0,908 \mathrm{a}$ & $0,909 a$ & $(-)$ \\
\hline $\mathrm{CV}$ & & & $4,918 \%$ & & \\
\hline \multicolumn{6}{|l|}{35 hspt } \\
\hline $0 \mathrm{ppm}$ & 0,000 & 0,000 & 0,000 & 0,000 & $0,000 \mathrm{q}$ \\
\hline 3 ppm & 0,957 & 0,963 & 0,954 & 0,939 & $0,953 p$ \\
\hline 6 ppm & 0,948 & 0,961 & 0,949 & 0,947 & $0,951 p$ \\
\hline 9 ppm & 0,944 & 0,950 & 0,940 & 0,927 & $0,940 p$ \\
\hline Rerata & $0,712 \mathrm{a}$ & $0,718 \mathrm{a}$ & $0,711 a$ & $0,703 \mathrm{a}$ & $(-)$ \\
\hline $\mathrm{CV}$ & & & $2,014 \%$ & & \\
\hline
\end{tabular}

Keterangan : Rerata dalam satu kolom atau baris yang diikuti oleh huruf sama tidak berbeda nyata menurut uji Duncan dengan tingkat kepercayaan 95\%. Tanda (-) menunjukkan tidak ada interaksi.

Tabel 16. Indeks konsumsi sawi hijau

\begin{tabular}{|c|c|c|c|c|c|}
\hline \multirow{2}{*}{$\begin{array}{c}\text { Konsentrasi } \\
\text { Fe }\end{array}$} & \multicolumn{4}{|c|}{ Tekanan Aerasi } & \multirow{2}{*}{ Rerata } \\
\hline & $0 \mathrm{mPa}$ & $0,003 \mathrm{mPa}$ & $0,006 \mathrm{mPa}$ & $0,012 \mathrm{mPa}$ & \\
\hline \multicolumn{6}{|l|}{$21 \mathrm{hspt}$} \\
\hline $0 \mathrm{ppm}$ & 0,721 & 0,872 & 0,775 & 0,825 & $0,798 \mathrm{q}$ \\
\hline 3 ppm & 0,897 & 0,900 & 0,896 & 0,872 & $0,891 p$ \\
\hline $6 \mathrm{ppm}$ & 0,898 & 0,890 & 0,887 & 0,881 & $0,889 p$ \\
\hline 9 ppm & 0,881 & 0,884 & 0,888 & 0,889 & $0,885 p$ \\
\hline Rerata & 0,849 a & 0,886 a & $0,861 \mathrm{a}$ & $0,867 a$ & $(-)$ \\
\hline $\mathrm{CV}$ & \multicolumn{5}{|c|}{$5,234 \%$} \\
\hline \multicolumn{6}{|l|}{35 hspt } \\
\hline $0 \mathrm{ppm}$ & 0,000 & 0,000 & 0,000 & 0,000 & $0,000 \mathrm{q}$ \\
\hline 3 ppm & 0,912 & 0,921 & 1,611 & 1,148 & $1,148 p$ \\
\hline $6 \mathrm{ppm}$ & 0,906 & 0,897 & 2,601 & 1,468 & $1,468 p$ \\
\hline 9 ppm & 0,917 & 0,948 & 3,622 & 1,829 & $1,829 p$ \\
\hline Rerata & $0,684 a$ & $0,691 \mathrm{a}$ & 1.958 a & $1,111 \mathrm{a}$ & $(-)$ \\
\hline
\end{tabular}

Keterangan: Rerata dalam satu kolom atau baris yang diikuti oleh huruf sama tidak berbeda nyata menurut uji Duncan dengan tingkat kepercayaan 95\%. Tanda (-) menunjukkan tidak ada interaksi.

Tabel 15 dan Tabel 16 memberikan informasi bahwa perlakuan konsentrasi 0 ppm memiliki indeks panen dan indeks konsumsi yang nyata lebih rendah jika dibandingkan dengan perlakuan lainnya karena bobot segar tajuk dan total pada perlakuan tersebut juga lebih rendah. Konsentrasi Fe 3 ppm, 6 ppm, dan 9 ppm memiliki indeks konsumsi yang seragam. Bobot segar bagian tanaman yang dapat dikonsumsi pada ketiga perlakuan ini juga seragam karena memiliki kualitas pertumbuhan yang sama. 
Pemberian aerasi dalam sistem budidaya tanaman secara hidroponik rakit apung dilakukan untuk mengatasi keterbatasan oksigen di daerah perakaran. Oksigen memiliki peran penting kaitannya dengan respirasi.

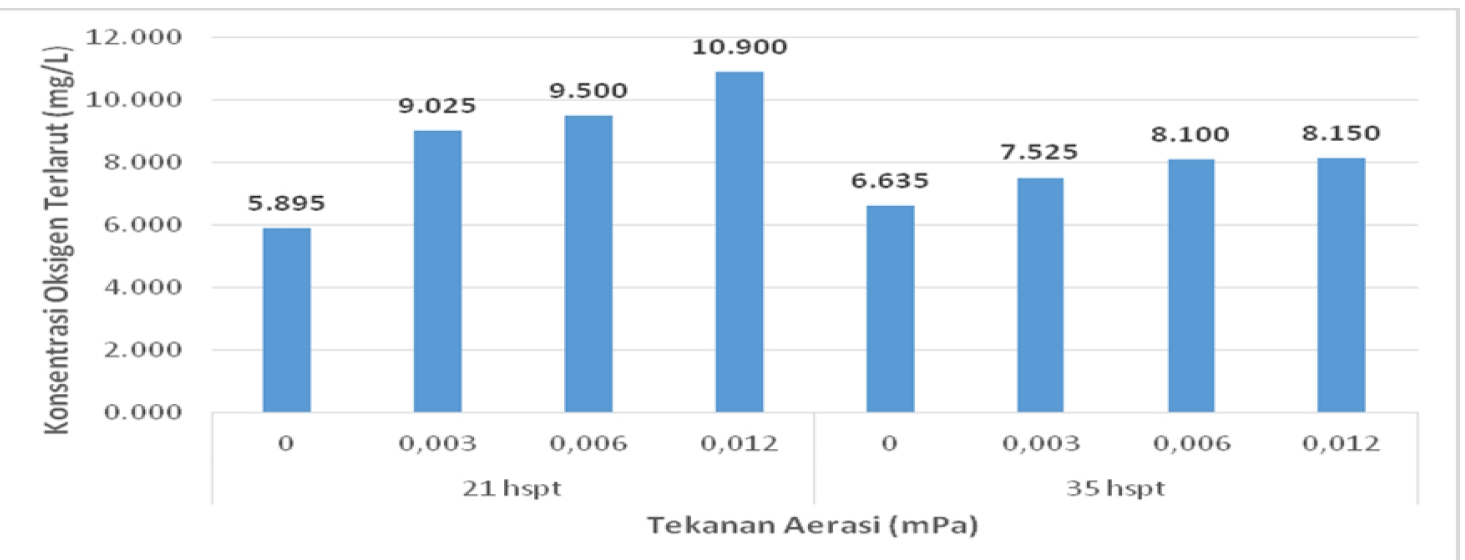

Gambar 2. Dinamika konsentrasi oksigen terlarut dalam larutannutrisi hidroponik pada saat tanaman sawi hijaurumur $21 \mathrm{hspt}$ dan $35 \mathrm{hspt}$

Pada penelitian ini, perlakuan pemberian aerasi secara individual tidak berpengaruh nyata terhadap pertumbuhan tajuk, hasil, dan kadar Fe sawi hijau. Hal ini dapat dipengaruhi oleh kedalaman larutan nutrisi. Kedalaman larutan nutrisi pada penelitian ini relatif dangkal yaitu $\geq 5 \mathrm{~cm}$, sehingga konsentrasi oksigen terlarut yang terukur cukup tinggi di semua level perlakuan tekanan aerasi yaitu $>5 \mathrm{mg} / \mathrm{L}$. Kedalaman larutan nutrisi yang ideal pada sistem deep water culture yaitu antara 20-25 $\mathrm{cm}$, sedangkan pada penelitian ini jauh dari kedalaman larutan nutrisi yang ideal. Oleh karena itu, perlakuan tekanan aerasi pada penelitian ini belum mampu menggambarkan pengaruh perbedaan konsentrasi oksigen terhadap pertumbuhan tajuk, hasil, dan kadar Fe tanaman sawi hijau.

\section{KESIMPULAN}

1. Pemberian tekanan aerasi pada larutan nutrisi hidroponik rakit apung sampai dengan 0,012 $\mathrm{mPa}$ tidak meningkatkan pertumbuhan tajuk, hasil, dan kadar Fe sawi hijau. Hal ini dipengaruhi oleh kedalaman larutan nutrisi hidroponik yang relatif dangkal, sehingga konsentrasi oksigen terlarut yang terukur cukup tinggi di semua level perlakuan tekanan aerasi.

2. Kadar dan serapan Fe organ daun sawi hijau meningkat sejalan dengan kenaikan konsentrasi Fe yang diberikan sampai dengan 9 ppm. Namun demikian pertumbuhan tajuk dan hasilnya sama pada semua aras konsentrasi F. 


\section{DAFTAR PUSTAKA}

Arisman, M.B., 2004. Gizi dalam Daur Kehidupan. Penerbit Buku Kedokteran EGC, Jakarta.

Direktorat Gizi Departemen Kesehatan Republik Indonesia, 1981. Daftar Komposisi Bahan Makanan. Bhatara Karya Aksara, Jakarta.

Febriani, D.N.S., 2011. Pengaruh pemotongan akar dan lama aerasi media terhadap pertumbuhan selada (Lactuca sativa L.) pada nutrient film technique system. Skripsi, Program Sarjana, Fakultas Pertanian, Universitas Gadjah Mada, Yogyakarta.

Mohammed, A.A. dan A.A. Aly, 2004. Iron deficiency stimulated some enzymes activity, lipid peroxidation and free radicals production in borage officinalis induced in vitro. International Journal of Agriculture and Biology, 6: 179-184.

Notoadmadjo, S. 2003. Prinsip-prinsip Dasar IImu Kesehatan Masyarakat. Rineke Cipta, Jakarta. 